\title{
Combinatorial therapy with an IL-15 superagonist (ALT-803) and anti-PD-L1 mAb augment T cell mediated anti-tumor immunity in mice
}

\author{
Christopher B Johnson ${ }^{1}$, Brian Riesenberg ${ }^{1}$, Dan Neitzke ${ }^{1}$, Emily K Jeng ${ }^{2}$, Warren D Marcus², David Cole ${ }^{1}$, \\ Hing C Wong ${ }^{2}$, Mark P Rubinstein ${ }^{1 *}$ \\ From Society for Immunotherapy of Cancer 29th Annual Meeting \\ National Harbor, MD, USA. 6-9 November 2014
}

The adoptive transfer of tumor-reactive $\mathrm{T}$ cells has shown great promise in treating patients with metastatic cancer. However, effective $\mathrm{T}$ cell responses are limited by the availability of $\mathrm{T}$ cell growth factors such as IL-2 and tumor-induced suppressive pathways. As tumor-induced suppression may hamper cytokine responsiveness, we hypothesized that combinatorial therapy providing exogenous cytokine with blockade of inhibitory pathways would lead to synergistic anti-tumor responses. We evaluated this hypothesis by treating mice with palpable B16 melanoma tumors with lymphodepletion and transfer of activated, tumor-reactive $\mathrm{CD} 8^{+} \mathrm{T}$ cells (pmel-1 TCR transgenic). The persistence of the adoptively transferred tumor-reactive $\mathrm{CD}^{+} \mathrm{T}$ cells was dramatically augmented in the recipient mice with injections of an IL-15 superagonist (ALT-803) which, compared with IL-2, has greater biological activity and does not expand $\mathrm{T}$ regulatory cells. The ALT-803-treated mice also survived significantly longer than the untreated mice. B16 melanoma tumor cells were found to express PD-L1 and activated CD8 ${ }^{+} \mathrm{T}$ cells have PD-1 on their surface. Thus, we also gave mice anti-PD-L1 mAb treatment to block this PD-1/PD-L-1 inhibitory pathway. Our preliminary data suggest that combinatorial therapy with anti-PD-L1 mAb led to synergistic improvement in anti-tumor efficacy. We are now determining the optimal timing and dosing of ALT-803 and anti-PD-L1 mAb therapy to confirm these results. Currently, ALT-803 is in clinical trials for treating patients with various solid and hematologic tumors. Our findings suggest combinatorial therapy relieving $\mathrm{T}$ cell dysfunction using checkpoint inhibitors and providing ALT-803

Medical University of South Carolina, Charlestown, SC, USA

Full list of author information is available at the end of the article cytokine therapy may lead to substantially improved outcomes over currently available therapies for patients with metastatic cancer.

\section{Authors' details}

${ }^{1}$ Medical University of South Carolina, Charlestown, SC, USA. ${ }^{2}$ Altor BioScience Corporation, Miramar, FL, USA.

Published: 6 November 2014

doi:10.1186/2051-1426-2-S3-P234

Cite this article as: Johnson et al:: Combinatorial therapy with an IL-15 superagonist (ALT-803) and anti-PD-L1 mAb augment T cell mediated anti-tumor immunity in mice. Journal for ImmunoTherapy of Cancer 2014 2(Suppl 3):P234.
Submit your next manuscript to BioMed Central and take full advantage of:

- Convenient online submission

- Thorough peer review

- No space constraints or color figure charges

- Immediate publication on acceptance

- Inclusion in PubMed, CAS, Scopus and Google Scholar

- Research which is freely available for redistribution
() Biomed Central 